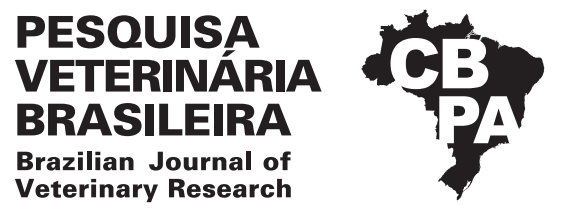

Pesq. Vet. Bras. 39(10):780-788, October 2019 DOI: 10.1590/1678-5150-PVB-6400

Original Article

ISSN 0100-736X (Print)

Livestock Diseases

ISSN 1678-5150 (Online)

\title{
Biochemical, endocrine, and histopathological profile of liver and kidneys of sheep with pregnancy toxemia ${ }^{1}$
}

\author{
Rodolfo J.C. Souto ${ }^{2 *} \mathbb{D}$, José A.B. Afonso², Carla L. Mendonça ${ }^{2}$, \\ Antônio Flávio M. Dantas ${ }^{3}$, Jobson F.P. Cajueiro² ${ }^{2}$ Daniel N.A. Gonçalves ${ }^{4}$, \\ Emanuel F. Olivera Filho ${ }^{4}$ and Pierre C. Soares ${ }^{5}$
}

\begin{abstract}
Souto R.C.J., Afonso J.A.B., Mendonça C.L., Dantas A.F.M., Cajueiro J.F.P., Gonçalves D.N.A., Oliveira Filho E.F. \& Soares P.C. 2019. Biochemical, endocrine, and histopathological profile of liver and kidneys of sheep with pregnancy toxemia. Pesquisa Veterinária Brasileira 39(10):780-788. Clínica de Bovinos, Universidade Federal Rural de Pernambuco, Campus Garanhuns, Av. Bom Pastor s/n, Cx. Postal 152, Boa Vista, Garanhuns, PE 55292-270, Brazil. E-mail: rodolfojcsouto@gmail.com

The objective of the present study was to characterize the biochemical, hormonal, and mineral profile, and histopathology of the liver and kidneys, related to the severity of natural cases of pregnancy toxemia (PT) in sheep. A total of 45 sheep with PT were analyzed at the "Clínica de Bovinos", Campus Garanhuns-UFRPE. The animals were submitted to clinical examination, followed by the collection of blood and urine. A necropsy was performed on thirteen animals that died and a histopathological examination was performed on samples of liver and kidneys. Increased creatinine, urea, glucose, fructosamine, non-esterified fatty acids, $\beta$-hydroxybutyrate, cortisol, chlorine, amylase, aspartate aminotransferase, gamma-glutamyltransferase, and folic acid were found, whereas insulin, potassium, and total and ionizable calcium presented low values for the species. Total protein, albumin, globulin, sodium, magnesium, and vitamin B12 remained within the normal range. In the macroscopic analysis of the liver, it was possible to observe an increase in organ and border size, yellowish coloration and parenchyma that varied from firm to friable. Vacuolation of the hepatocytes and renal tubular cells was observed. Metabolic disorders in sheep associated with hepatic and renal lesions are more apparent in overweight animals. With the greater impairment in hepatic and renal function, the clinical prognosis of animals with a high body score should be considered reserved.
\end{abstract}

INDEX TERMS: Biochemistry, endocrine, histopathology, liver, kidneys, sheep, pregnancy toxemia, clinical biochemistry, metabolic profile, energy deficiency, anatomopathological lesions, ovine.

RESUMO.- [Perfil bioquímico, endócrino e histopatológico do fígado e rins de ovelhas com toxemia na prenhez.] Objetivou-se caracterizar o perfil bioquímico, hormonal,

\footnotetext{
${ }^{1}$ Received on June 18, 2019.

Accepted for publication on July 3, 2019.

${ }^{2}$ Clínica de Bovinos, Universidade Federal Rural de Pernambuco (UFRPE), Campus Garanhuns, Av. Bom Pastor s/n, Boa Vista, Garanhuns, PE 55292270, Brazil. *Corresponding author: rodolfojcsouto@gmail.com

${ }^{3}$ Universidade Federal de Campina Grande (UFCG), Campus Patos, Av. 23 de Agosto 860, Centro, Barra, BA 47100-000, Brazil.

${ }^{4}$ Departamento de Medicina Veterinária, Universidade Federal Rural de Pernambuco (UFRPE), Dois Irmãos, Recife, PE 52171-900, Brazil.

${ }^{5}$ Professor Associado, Departamento de Medicina Veterinária, Universidade Federal Rural de Pernambuco (UFRPE), Rua Dom Manoel de Medeiros s/n, Dois Irmãos, Recife, PE 52171-900.
}

mineral e a histopatologia hepática e renal, relacionando com a severidade de casos naturais de toxemia da prenhez (TP) em ovelhas. Analisou-se 45 ovelhas na Clínica de Bovinos, Campus Garanhuns-UFRPE, com TP. Foram submetidas ao exame clínico, seguido de coleta de sangue e urina. Treze animais que vieram a óbito foram necropsiados, nas amostras de fígado e rins realizou-se exame histopatológico. Revelou-se elevação de creatinina, ureia, glicose, frutosamina, ácidos graxos não esterificados, $\beta$-hidroxibutirato, cortisol, cloro, amilase, aspartato aminotransferase, gama glutamiltransferase e ácido fólico, enquanto insulina, potássio, cálcio total e ionizável apresentaram valores abaixo para os da espécie. A proteína total, albumina, globulina, sódio, magnésio e vitamina B12 mantiveram-se dentro da normalidade. Na análise macroscópica do fígado, pôde-se observar aumento de tamanho 
do órgão e dos bordos, coloração amarelada e parênquima que variava de firme a friável. Observou-se vacuolização dos hepatócitos e das células tubulares renais. Os transtornos metabólicos nas ovelhas associados às lesões hepáticas e renais são mais aparentes nos animais com sobrepeso. Com o maior comprometimento da função hepática e renal, o prognóstico clínico dos animais com escore corporal elevado há de ser considerado reservado.

TERMOS DE INDEXAÇÃO: Endócrino, histopatológia, fígado, rins, ovelhas, gravidez, bioquímica clínica, perfil metabólico, deficiência de energia, toxemia da prenhez, lesões anatomopatológicas, ovinos.

\section{INTRODUCTION}

Pregnancy toxemia (PT) is a metabolic disorder that occurs in sheep and goats carrying twins or triplets, although it may occur in simple pregnancies with large fetuses, during the last 4 to 6 weeks of gestation, when there is an increase in energy demand due to rapid fetal growth. This condition, associated with factors that induce a reduction in food intake, such as obesity and inadequate diet supply, contribute to the duration and magnitude of the negative energy balance and predisposition to the onset of the disease in its subclinical or clinical form (González \& Silva 2006, Radostits et al. 2007).

The disease manifests more frequently in intensive than extensive systems of production (Corrêa et al. 2010), and can be classified as type I when linked to undernourishment during pregnancy or type II which usually occurs in sheep that are very obese (Ortolani 2004). The clinical manifestation is characterized by depression, weakening, reduction in food intake, respiratory alterations, and nervous symptoms. There is hypoglycemia, hyperketonemia, ketonuria, and fat deposition in the liver, which can be severe (Hefnawy et al. 2011, González et al. 2012, Lima et al. 2012).

A framework of metabolic acidosis has been observed in PT, with an increase in the concentration of NEFAs, $\beta$-hydroxybutyrate, and anion gap, and a decrease in blood $\mathrm{pH}$, bicarbonate concentration, and base excess, as well as marked alterations in the electrolytic profile involving the calcium, phosphorus, chlorine, sodium, and potassium ions (Hefnawy et al. 2011, González et al. 2012, Lima et al. 2012). Furthermore, hormonal alterations are closely involved in the development of ketosis in ruminants (Brockman 1979).

Hepatic and renal function are usually compromised as a result of fatty infiltration, which due to its severity may interfere with gluconeogenic capacity, contributing to ketosis and azotemia indicative of severe renal damage (Parry \& Taylor 1956, Wastney et al. 1983, Van Saun 2000, Cal et al. 2009 , Yarim \& Ciftci 2009). PT in sheep is a complex disease and often presents poor treatment prognosis. Thus, a better understanding is required in terms of its biochemical and hormonal behavior and the consequences of these alterations on vital organs such as the kidneys and liver, especially in the occurrence of spontaneous cases.

Studies that report the dynamics of biomarkers indicating the severity of cases of pregnancy toxemia are still scarce, particularly in relation to treatment of the situation. In view of the above, the objective was to characterize the profile of different biochemical, hormonal, and histopathological characteristics of the liver and kidneys of natural cases of PT in sheep.

\section{MATERIALS AND METHODS}

Data from 45 sheep reared in the state of Pernambuco were included, of the breeds Santa Inês, Dorper, and mixed, aged from one to seven years, with a mean weight of $67 \mathrm{~kg}$, mostly multiparous, and predominantly submitted to semi-intensive and intensive rearing. The majority of animals received a body score of three or above and their diet was based on concentrates. The clinical examination was performed according to Radostits et al. (2007), and the animals were submitted to an ultrasound examination to determine fetal viability.

Blood samples were collected through jugular venipuncture using a $25 \times 8 \mathrm{~mm}$ needle into vacutainer siliconized tubes and centrifuged ${ }^{6}$ at $3500 \mathrm{RPM}$ for five minutes with anticoagulant sodium fluoride/oxalate to obtain plasma and determination of glucose. The samples obtained in tubes without anticoagulant, to obtain the serum, were used in the biochemical and hormonal analyzes. The samples were conditioned in the form of aliquots of serum and plasma in Eppendorf tubes and stored in an ultra-freezer at a temperature of $-80^{\circ} \mathrm{C}^{7}$.

The evaluated components were: total protein ${ }^{8}$, albumin ${ }^{8}$, urea $^{8}$, creatinin ${ }^{8}$, fructosamine ${ }^{8}$, amylase $\mathrm{CNPG}^{8}$, aspartate aminotransferase $(\mathrm{AST})^{8}$, gamma-glutamyltransferase $(\mathrm{GGT})^{8}$, creatine kinase $(\mathrm{CK})^{8}$, calcium liquiform (total calcium) ${ }^{8}$, phosphorus UV Liquiform ${ }^{8}$, magnesium ${ }^{8}$, and chlorides ${ }^{8}$ performed in a semi-automated biochemical analyzer, LabQuest ${ }^{8}$ using commercial reagents ${ }^{8}$. The variables sodium ${ }^{9}$ and potassium were determined ${ }^{9}$ using a flame photometer of the brand Benfer ${ }^{\circledR 9}$. The globulin values were obtained by subtracting the albumin value from the total protein, the ionized calcium using a calculation involving the value of albumin, total protein, and total calcium (methodology used by the manufacturer - Doles ${ }^{10}$ ), and the calcium:phosphorus ratio by dividing the value of total calcium by the value of phosphorus. The non-esterified fatty acids (NEFA) and $\beta$-hydroxybutyrate (BHB) were determined according to commercial reagents (Randox Laboratories Ltd) ${ }^{11}$ and for the hormonal determinations of cortisol and insulin, folic acid, and vitamin B12 the electrochemiluminescence technique was used $^{12}$, with commercial reagents $\left(\text { Cobas }^{\circledR}\right)^{12}$. Evaluation of ketone bodies was carried out on urine collected by means of spontaneous micturition using urinalysis reagent strips (Dirksen et al. 1993).

The sick animals that had died were submitted to necropsy. The kidneys and liver were collected for macroscopic and histological analysis. The collected material was fixed in $10 \%$ formalin, embedded in paraffin, cut 4-5 micrometers thick, and stained with hematoxylin-eosin (HE). The slides were read using light microscopy. In order to evaluate the degree of the lesions as a function of the body score, two groups were established: Group 1 with a score of up to three $(n=7)$ or Group 2 with a score higher

6 Centrifuga Fanem Ltda Baby I, Mod. 206, Av. General Ataliba Leonel 1790, São Paulo, SP 02033-020, Brazil.

7 Ultralow freezer NuAire Inc., 2100 Fernbrook Lane N. Plymouth, MN 55447, USA.

8 Labtest Diagnóstica S.A., Av. Paulo Ferreira da Costa 600, Lagoa Santa, Minas Gerais, MG 33400-000, Brazil.

9 Benfer, Produtos para laboratórios, Rua Padre Agostinho Poncet 74, São Paulo, SP 02408-040, Brazil.

10 Doles, Rodovia BR-153 Km 493, Lote 7, Chácara Retiro, Goiânia, G0 74665833, Brazil.

11 Randox Laboratories Ltd, Ardmore, Diamond Road, Crumlin, Co. Antrim, United Kingdom BT 29 4QY, UK.

12 Cobas e 411, Roche Sistemas de Diagnósticos Ltda, Avenida Eng. Billings 1729, Jaguaré, São Paulo, SP 05321-900, Brazil. 
than three $(n=6)$. The histopathological lesions of the liver were classified by the degree of intensity and distribution in the three areas of the parenchyma, area 1 comprising the periportal, area 2 the midzonal, and area 3 the centrilobular.

The data were processed considering measures of central tendency and absolute and relative frequencies. Pearson's correlation coefficient was determined by association between pairs of variables. The significance obtained in the correlation was performed according to Little \& Hills (1978). The data were analyzed using the Statistical Analysis System (SAS 2009). In relation to the liver and kidneys the data were recorded descriptively.

The project obtained a positive opinion from the Ethics Committee on the Use of Animals (CEUA), "Universidade Federal Rural de Pernambuco" (UFRPE), license number: 024/2012 of CEPE-FRPE according to COBEA standards and the National Institute of Health Guide for Care and Use of Laboratory Animals.

\section{RESULTS}

Of the 45 sheep with PT evaluated, $82.90 \%$ were normoglycemic and/or hyperglycemic, while only $17.10 \%$ were hypoglycemic. The mean number of lambs per birth per ewe was higher in those that were hyperglycemic and hypoglycemic, while normoglycemic sheep presented the lowest mean. The lowest number of deaths occurred in sheep in a hypoglycemic phase $1 / 7$ (14.28\%), followed by hyperglycemic $4 / 23$ (17.39\%), and normoglycemic $4 / 11$ (36.36\%) (Table 1). In the sheep from which urine was harvested, ketonuria was found in all of them.

High values of creatinine, urea, fructosamine, NEFEs, BHB, cortisol, chlorides, amylase, AST, GGT, and folic acid were also found, whereas the variables: insulin, potassium, and total and ionizable calcium were below reference values for the species. Other biochemical and electrolytic parameters, such as total protein, albumin, globulin, vitamin B12, phosphorus, sodium, and magnesium remained within the normal range (Table 2-6).

A high-intensity negative relationship was observed between the serum cortisol concentration and insulin ( $r=-0.71)$, a high intensity positive relationship between creatinine and urea $(\mathrm{r}=0.71)$, and between total calcium and insulin $(\mathrm{r}=0.65)$, and a positive moderate ratio was observed between glucose and insulin concentration ( $\mathrm{r}=0.47$ ) (Fig.1).

Table 1. Mean and standard deviation values $(x \pm s)$ of the glycemic profile, number of animals, number of offspring, and clinical outcome of sheep with PT, attended at the "Clínica de Bovinos", Campus Garanhuns-UFRPE

\begin{tabular}{|c|c|c|c|c|c|}
\hline \multirow{2}{*}{ Clinical condition } & \multirow{2}{*}{$\begin{array}{l}\text { Glycemic condition } \\
(\mathrm{mmol} / \mathrm{L})\end{array}$} & \multirow{2}{*}{ Number of animals } & \multirow{2}{*}{$\begin{array}{c}\text { Number and average of } \\
\text { lambs/ewes }\end{array}$} & \multicolumn{2}{|c|}{ Outcome } \\
\hline & & & & Healing & Death \\
\hline Hypoglicemics & $2.43 \pm 0.29$ & $07(17.10 \%)$ & $14(x=2.00)$ & 6 & 1 \\
\hline Normoglycemics & $3.83 \pm 0.40$ & $13(31.70 \%)$ & $22(x=1.83)$ & 7 & 4 \\
\hline Hyperglycemics & $7.34 \pm 1.72$ & $21(51.20 \%)$ & $44(x=2.09)$ & 19 & 4 \\
\hline
\end{tabular}

Table 2. Mean, standard deviation, minimum and maximum values of biochemical (protein) parameters in sheep affected with PT, attended at the "Clínica de Bovinos", Campus Garanhuns-UFRPE, from 2007 to 2012

\begin{tabular}{|c|c|c|c|c|c|}
\hline Parameters & Means & Standard deviation & Minimum & Maximum & Reference values \\
\hline Creatinine $(\mu \mathrm{mol} / \mathrm{L})$ & 175.82 & 161.77 & 43.32 & 685.10 & $106.08-167.96^{a}$ \\
\hline Urea (mmol/L) & 10.25 & 8.86 & 2.85 & 48.84 & $2.91-7.28^{\mathrm{a}}$ \\
\hline Total Protein(g/L) & 75.20 & 15.08 & 45.40 & 108.20 & $60.0-79.0^{\mathrm{a}}$ \\
\hline Albumin (g/L) & 29.35 & 8.79 & 15.30 & 64.90 & $24.0-30.0^{\mathrm{a}}$ \\
\hline Globulin (g/L) & 45.82 & 15.07 & 7.20 & 83.50 & $35-57^{a}$ \\
\hline
\end{tabular}

a Source: Kaneko et al. (2008).

Table 3. Mean, standard deviation, minimum and maximum values of biochemical (energy) parameters, in sheep affected with PT, attended at the “Clínica de Bovinos", Campus Garanhuns-UFRPE, from 2007 to 2012

\begin{tabular}{|c|c|c|c|c|c|}
\hline Parameters & Means & Standard deviation & Minimum & Maximum & Reference values \\
\hline Glucose (mmol/L) & 5.39 & 2.42 & 2.22 & 11.22 & $2.8-4.48^{a}$ \\
\hline Fructosamine $(\mu \mathrm{mol} / \mathrm{L})$ & 195.33 & 44.61 & 119.36 & 337.51 & $172 \pm 2.0^{\mathrm{b}}$ \\
\hline NEFA (mmol/L) & 1.15 & 0.59 & 0.23 & 3.10 & $<0.4^{\mathrm{a}}$ \\
\hline $\mathrm{BHB}(\mathrm{mmol} / \mathrm{L})$ & 1.39 & 1.18 & 0.30 & 5.08 & $<0.6^{c}$ \\
\hline Folic Acid (ng/ml) & 11.63 & 7.38 & 2.76 & 20.00 & $1.94-3.16^{\mathrm{d}}$ \\
\hline Vitamin $B_{12}(\mathrm{pg} / \mathrm{ml})$ & 1781.88 & 459.65 & 279.00 & 2000.00 & $1494.71-1842.89^{d}$ \\
\hline
\end{tabular}

Source: ${ }^{\text {a }}$ Kaneko et al. (2008), ${ }^{\text {b }}$ Cantley et al. (1991), ${ }^{\text {c }}$ Contreras \& Wittwer (2000), ${ }^{\text {d }}$ Carvalho (2013). 
Table 4. Mean, standard deviation, minimum and maximum values of biochemical (enzyme) parameters, in sheep affected with PT, attended at the "Clínica de Bovinos", Campus Garanhuns-UFRPE, from 2007 to 2012

\begin{tabular}{lccccc}
\hline \multicolumn{1}{c}{ Parameters } & Means & Standard deviation & Minimum & Maximum & Reference values \\
\hline Amylase (U/L) & 33.60 & 26.79 & 7.90 & 134.40 & $7.76-11.5^{\mathrm{a}}$ \\
AST (U/L) & 308.21 & 133.53 & 107.36 & 639.05 & $60-280^{\mathrm{b}}$ \\
GGT (U/L) & 83.81 & 52.47 & 38.25 & 237.15 & $20-52^{\mathrm{b}}$
\end{tabular}

Source: ${ }^{\mathrm{a}}$ Araújo \& Silva (2008), ${ }^{\mathrm{b}}$ Kaneko et al. (2008).

Table 5. Mean, standard deviation, minimum and maximum values of biochemical (electrolyte) parameters, in sheep affected with PT, attended at the "Clínica de Bovinos", Campus Garanhuns-UFRPE, from 2007 to 2012

\begin{tabular}{|c|c|c|c|c|c|}
\hline Parameters & Means & Standard deviation & Minimum & Maximum & Reference values \\
\hline Total Calcium (mmol/L) & 2.1 & 0.74 & 0.65 & 18.70 & $2.88-3.2^{\mathrm{a}}$ \\
\hline Ionized Calcium (mmol/L) & 1.15 & 0.38 & 0.36 & 2.05 & $1.49-1.73^{\mathrm{a}}$ \\
\hline Ca:P (mmol/L) & 1.22 & 0.71 & 0.21 & 3.55 & $1: 4-1: 6^{c}$ \\
\hline $\mathrm{Mg}(\mathrm{mmol} / \mathrm{L})$ & 1.00 & 0.27 & 0.48 & 1.80 & $0.7-1.1^{\mathrm{b}}$ \\
\hline $\mathrm{Na}(\mathrm{mmol} / \mathrm{L})$ & 139.25 & 9.60 & 120.00 & 161.00 & $139-152^{\mathrm{a}}$ \\
\hline
\end{tabular}

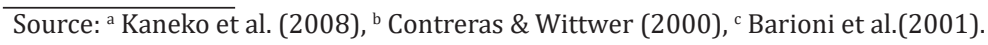
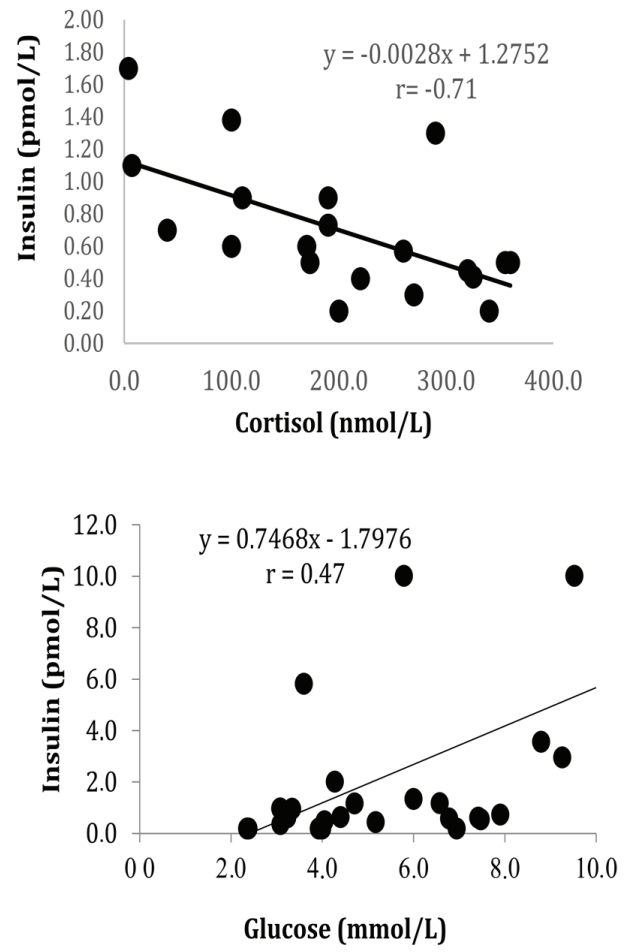

G
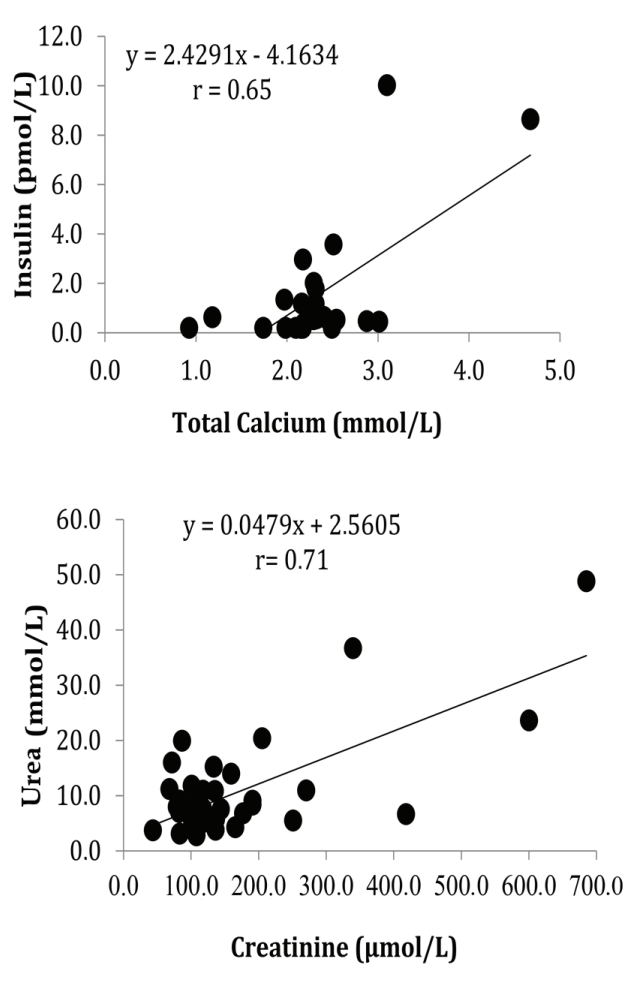

Fig.1. Relationship between metabolic profile components in ewes with pregnancy toxemia.

Table 6. Mean, standard deviation, minimum and maximum values of hormonal parameters, in sheep affected with PT, attended at the "Clínica de Bovinos", Campus Garanhuns-UFRPE, from 2007 to 2012

\begin{tabular}{lrccrc}
\hline \multicolumn{1}{c}{ Parameters } & Means & Standard deviation & Minimum & Maximum & Reference values \\
\hline Cortisol (nmol/L) & 287.76 & 348.53 & 3.48 & 1345.00 & $62 \pm 10^{\mathrm{a}}$ \\
Insulin (pmol/L) & 2.33 & 3.53 & 0.20 & 14.27 & $117 \pm 0.6^{\mathrm{b}}$
\end{tabular}

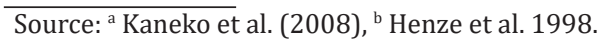


The majority of livers of the animals with Group 1 PT (n=7) presented a slight increase in liver and border size. The yellowish coloration on the surface was also present at the cut. In the animals of Group $2(n=6)$ these findings were more expressive regarding the intensity (Fig.2). The kidneys did not present marked alterations, with a pale surface appearance in some of the lean animals, and slight yellowish coloration in fat animals. Of the lesions found in the liver and kidneys, only cell vacuolation was considered to be directly related to the metabolic disorder. Thus, we attempted to establish a parallel between ECC (Groups 1 and 2), the degree of intensity, and distribution of cellular vacuolations.

Regarding the findings for the liver, in Group $142.86 \%$ (3) presented unusual vacuolization while in $57.14 \%$ (4) of the cases it was discrete. The lesions were distributed as follows: in $42.86 \%$ (3), these were located in zone I, $28.57 \%$ of the animals (2) presented vacuolization in zones 1 and 2, and $28.57 \%$ (2) were in zone 3 . Regarding the renal lesions, only

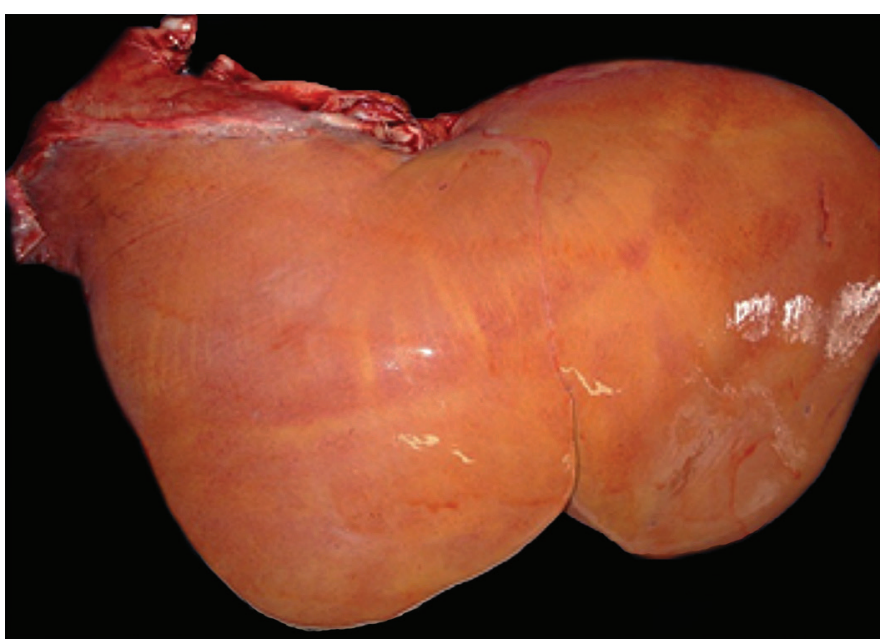

Fig.2. Enlarged liver with yellowish coloration in sheep with pregnancy toxemia.
$28.57 \%$ of the animals (2) presented unusual vacuolations in tubular epithelial cells.

With respect to the degree of vacuolization in the liver of the animals in Group 2, severe lesions were found in 33.33\% (2), moderate lesions in $33.33 \%$ (2), discrete lesions in $16.67 \%$ (1), and unusual lesions in only $16.67 \%$ (1). The hepatic lesions were distributed as follows: $66.67 \%$ (4), presented lesions in the three zones, $16.67 \%$ (1) in zones 1 and 3, and $16.67 \%$ (1) in zone 3 (Fig.3A). Regarding the renal lesions: 33.33\% (2) presented a marked lesion of vacuolations in tubular epithelial cells, in $33.33 \%$ (2) these were sparse, but in one of these the tubular cells affected were in the cortical and cortical-medullary regions (Fig.3B). The others did not present fatty infiltration in their structure.

\section{DISCUSSION}

The increase in blood glucose in the majority of animals is in agreement with that described in the literature when defining PT (Scott et al. 1995, Corrêa et al. 2010), which reports a decrease in serum glucose concentration as the most frequent finding, which, according to Afonso (2006) is initially found in the disease, however with disease progression, glycemic levels tend to stabilize, with some sheep presenting a framework of hyperglycemia, and in these cases the prognosis is unfavorable as the fetuses are probably dead. According to Pereira et al. (2010), at the end of gestation sheep present a lower ability to metabolize glucose, with rising glycemic levels possibly due to increased insulin resistance in peripheral tissues. However, this condition was not the only one found among the affected animals, normoglycemic sheep and a minority of hypoglycemic sheep composed the group, which is in agreement with the findings of Henze et al. (1998).

These findings focus attention on the importance of analysis of the glycemic condition of sheep with PT prior to the therapeutic administration of glucose by the parenteral route, considering that its administration when not necessary could lead to hyperglycemic shock and death of the female. The higher survival rate observed among hypoglycemic ewes may be related to the lower degree of stress and better
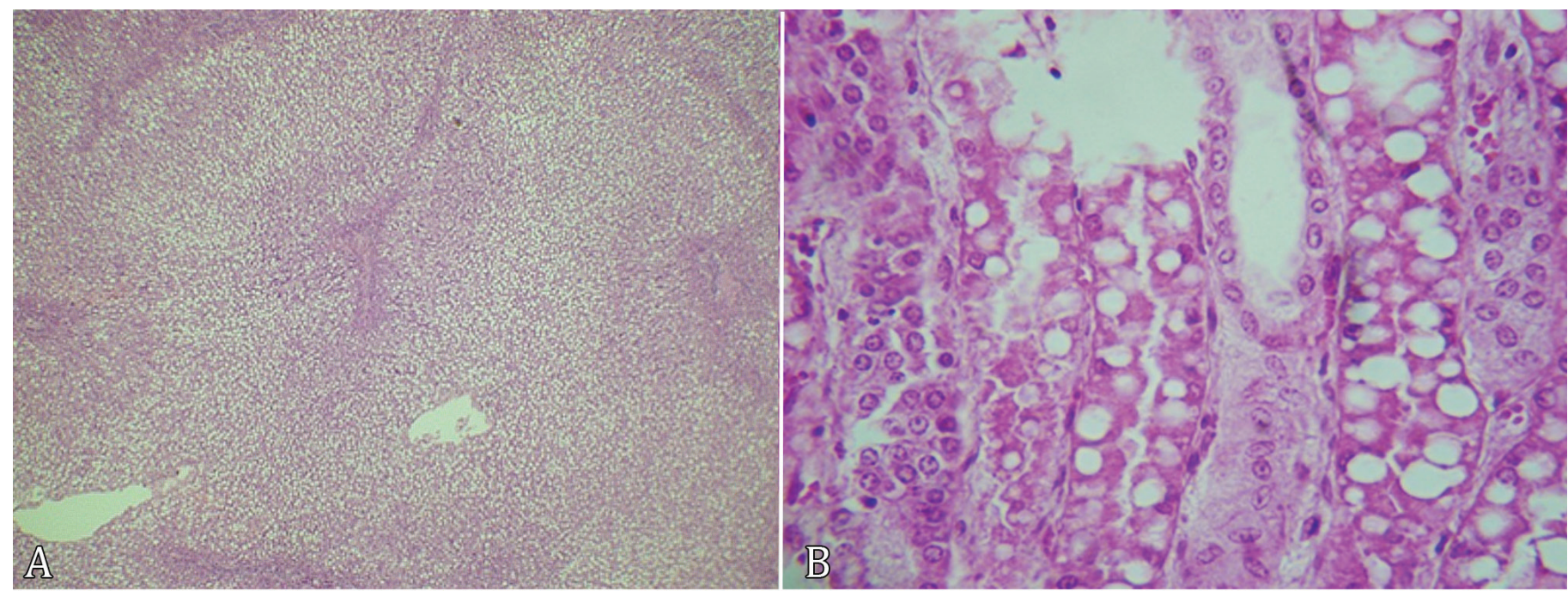

Fig.3. (A) Massive vacuolization of the hepatocyte cytoplasm in the three zones of the hepatic lobe in sheep with pregnancy toxemia. HE, obj.40x. (B) Vacuolization in tubular epithelial cells in sheep with pregnancy toxemia. HE, obj.40x. 
response to hypoglycemia compared to other glycemic conditions, provided that it is not severe enough to cause irreversible damage to the nervous system (Jeffrey \& Higgins 1992), findings in accordance with the results of Lima et al. (2012) who observed better results regarding fetal viability when intervention in goats with PT was performed in a hypoglycemic phase.

The albumin indices, which were found unchanged, resemble the reports by Cantley et al. (1991), Andrews et al. (1996), and VanSaun (2000) in sheep with metabolic disorder, however values lower than those considered normal, were verified by Yarim \& Ciftci (2009) and Hefnawy et al. (2011) which justify the reduction through hepatic or renal failure, as its synthesis occurs in the liver, due to the presence of fatty infiltration in animals with high lipomobilization. In relation to the total protein and globulin, for which indices were maintained within the normal range for the species, this differs from the findings of Cerón et al. (1994) and Yarim \& Ciftci (2009), where a reduction in these variables was verified in goats and sheep with PT and the authors explained this alteration through impaired hepatic function. Elevation in the values found for total serum protein in other studies is justified by the different degrees of dehydration intensity that animals with the disease can present (Cantley et al. 1991, VanSaun 2000).

The azotemia framework occurred due to possible renal alteration, considering that according to Reece (2006), free creatinine in the blood is not reused and is excreted in the urine. Reductions in creatinine clearance values are associated with elevated plasma concentrations and represent a loss in nephron numbers or reduced renal function. According to Afonso (2006) and Santos et al. (2011) a reserved prognosis should be attributed to the appearance of renal injury when evidenced by elevated creatinine concentration in cases of PT. Urea elevation may also be related to renal alteration, according to González \& Silva (2006) the kidneys have a high ability to excrete it, being filtered in the glomerulus and partially resorbed passively in the tubules. In ruminants, it can be excreted gastrointestinally, so that normal or not much elevated values can be found in cases of renal failure. According to Wastney et al. (1983), high concentrations associated with creatinine are indicative of severe renal failure in sheep with PT. However, the main limitation of these two variables is that they detect renal failure when $75 \%$ of the affected nephrons are reached (González \& Silva 2006).

Regarding the high values of fructosamine, this is due to the state of hyperglycemia found in the majority of affected sheep, a result that was observed by Santos et al. (2011), and distinct from that found by Cantley et al. (1991) who reported hypoglycemia in sheep with PT. It is important to study this variable as it is a stable ketoamine formed when glucose reacts non-enzymatically with amino groups in proteins, its concentration controlled by the equilibrium between the rates of synthesis and removal. Thus, the serum fructosamine concentration will increase with prolonged hyperglycemia or prolonged hyperproteinemia, tending to fall with increased protein renewal or prolonged hypoglycemia (Bernstein, 1987). Therefore, the concentration of fructosamine in peripheral blood varies according to the long-term state of glycemia and/or the protein metabolism of an individual, in the previous two week period (Murphy et al. 1997). Its use in cases of PT is even more important since according to Armbruster (1987) it is not subject to changes due to transient hyperglycemia, and that a single measurement of glucose shows only the momentary concentration which is subject to rapid and frequent changes, dependent on daily variations, dietary factors, and individual factors.

The elevation in NEFAs found in sheep with PT, according to Andrews (1997), portrays the magnitude of the metabolic disorder, and is explained by the lipolysis that occurred, indicating the existence of fat mobilization to meet greater energy demand from the sheep and fetuses. Increases in NEFAs were also found in sheep with PT by Sigurdsson (1991), VanSaun (2000), and Santos et al. (2011). However, for Regnault et al. (2004) and Corrêa et al. (2010), this elevation may point to a deleterious effect of NEFAs on the sensitivity and action of insulin, as well as knowing that these act by inhibiting the secretion of this hormone by $\beta$-pancreatic cells, and may even stimulate cellular apoptosis pathways. In addition, lower uptake of glucose, secondary to defects in the transduction of the insulin signal, has been reported, thus the glucose is spared and made available for use in the placenta and fetuses.

The elevation in $\beta$-hydroxybutyrate occurred due to the high degree of lipomobilization found with the consequent synthesis of NEFAs, which undergo $\beta$-oxidation and in excess form large amounts of ketone bodies. An increase in $\beta$-hydroxybutyrate concentration was observed by Scott et al. (1995), Andrews et al. (1996), Andrews (1997), Moghaddam \& Hassanpour (2008), Bani Ismail et al. (2008), and Hefnawy et al. (2010) in sheep and goats affected by the disease and although the ketone bodies are produced by the liver, they are used by other tissues, and ketosis could be the result of their underuse or excessive production. According to Harmeyer \& Schlumbohm (2006), this increase is caused by a reduction in the ability of pregnant females to use $\beta$-hydroxybutyrate and induces several adverse effects on energy balance and glucose metabolism, facilitating the development of PT, especially in sheep with twin/multiple pregnancies.

With respect to folic acid, information regarding its relationship with the disease under study is scarce, but the result found is similar to that of Carvalho (2013), who found an increase in the serum concentration of folic acid in sheep with PT in relation to healthy animals receiving diets with low and high energy density. Zinn et al. (1987) and Chiquette et al. (1993) with folic acid supplementation in bovines, observed a significant increase in propionate concentration and a tendency to reduce ruminal $\mathrm{pH}$. In this way it would be interesting to understand the dynamics of this vitamin related to the metabolic disorders that occur in sheep.

The high levels found for vitamin B12 were similar to those reported by Carvalho (2013), both in sheep receiving diets with high energy density and in diseased sheep with PT, this fact is justified, since the majority of the affected sheep were reared in semi-intensive and intensive systems, with diets rich in energy concentrate, which reflect in a body score above three in most animals. Therefore, due to the scarcity of information available, the determination of serum levels of vitamin B12 in sheep with PT is of extreme interest, since ruminants need, at the cellular level, all the vitamins for the proper functioning of their body and cobalamin (vitamin B12) participates in several metabolic activities.

According to Strobel (1992), vitamin B12 is fundamental in the energetic metabolism of sheep, since it acts as a cofactor in reactions that promote the production of propionic acid, the main precursor of glucose synthesized in the liver of sheep. Therefore, if a ruminant is deficient in vitamin B12 it presents decreased energy efficiency (Contreras \& Wittwer 2000). 
The elevation in amylase levels in sheep with PT may be related to an excessive supply of carbohydrates, since, according to Van Hellen et al. (1978), Harmon (1993), and Kaneko et al. (2008), the amylase synthesis in the pancreas in animals with high carbohydrate diets is increased, as it is responsible for catalyzing the specific hydrolysis of the $\alpha$-1,4-glycosidic bonds that are present in the starch, which escape fermentation and are digested until glucose in the small intestine. On the other hand, the increase in amylase may be a result of renal damage, corroborating with the elevated levels of serum urea and creatinine found in this regard. González \& Silva (2006), affirm that hyperamylasemia can be caused by decreased glomerular filtration, since it is eliminated in the urine.

The increase in liver enzymes AST and GGT was due to hepatic damage, since AST, according to González \& Silva (2006), is a good indicator of hepatic functioning in ruminants. In cases of PT, an increase in AST was observed by Henze et al. (1998) and Barakat et al. (2007). According to Kabakci et al. (2003) concentrations of the enzyme remained unchanged in sheep even 20 days after initiation of treatment. According to Cal et al. (2009) a positive correlation was found between the severity of histological lesions and AST. Santos et al. (2011) observed elevation of the enzyme only in the animals that died, while the GGT was elevated in all conditions presented by the disease. Thus, increases in GGT were observed in sheep with PT by Wierda et al. (1985), who reported that serum GGT and sorbitol dehydrogenase activity are good metabolic indicators of PT prognosis.

The decrease in serum calcium concentration found in sheep and goats with PT was reported in the works of Sigurdsson (1991), Brozos et al. (2011), and Hefnawy et al. (2011), which reinforces the idea of the importance of calcium in the metabolism of sheep at the end of gestation and its possible involvement in the pathogenesis of PT. According to Schlumbohm et al. (1997), hypocalcemia associated with decreased insulin target tissue responsiveness, occurring during late gestation, worsens this condition through the inhibitory effect on hepatic gluconeogenesis and by increasing insulin resistance in target tissues. Schlumbohm \& Harmeyer (2003) added that the combination of hypocalcemia and hyperketonemia has an additional effect in pregnant sheep on depression of the homeostatic glucose system. This information was strengthened by Schulla et al. (2003) who stated that insulin is secreted by pancreatic cells in response to elevation of cytoplasmic $\mathrm{Ca}^{2+}$ resulting from an increase in $\mathrm{Ca}^{2+}$ influx through the $\mathrm{Ca}^{2+}$ dependent voltage channels. This justifies the high positive relation found between these variables $(\mathrm{r}=0.65)$.

The chlorine and potassium elements presented an increase and decrease, respectively, in relation to the reference values for the ovine species, going against the findings of González et al. (2012), after induction and rapid intervention in goats under study, concluded that these electrolytes are not good initial indicators in the diagnosis of PT, as they do not present significant alteration, however, in natural cases, the intervention is usually later, which may have inferred in the results found. However, Henze et al. (1998) evaluated the spontaneous occurrence of PT and found a significant reduction in serum potassium levels in the sheep who died, attributing hypokalemia as a result of inadequate food intake and renal tubular absorption of potassium. According to Payne (1983), potassium plays a key role in certain enzymatic interactions, especially in those related to energy metabolism; however it is difficult for potassium deficiency to occur as the majority of foods contain proportions higher than those required by animals. On the other hand, cereals are comparatively poorer than forage and the current feed system rich in concentrates, intended to increase the level of production, has altered this pattern.

The decrease found in serum insulin levels in sheep with PT was also observed by Sigurdsson (1991) and Henze et al. (1998) who found a more pronounced decrease in those animals in a more serious and life-threatening clinical condition. Alterations in insulin behavior were analyzed by Petterson et al. (1993), who found development of insulin resistance in peripheral tissues in sheep, using glucose as part of the adjustment of metabolic adaptations that occur at the end of gestation. According to Araujo (2009), maternal insulin-dependent tissues are placed at a competitive disadvantage by the pregnant uterus which is insulin independent, thus the constant drainage of maternal glucose into fetuses results in lower production of insulin by pancreatic cells.

Higher cortisol levels differ from those found by Firat \& Özpinar (2002) in healthy sheep at the end of gestation. The authors observed a reduction in cortisol level concentrations at the end of gestation, but the increase was also noticed by Sigurdsson (1991) in cases of PT in sheep. According to Andrews (1997), serum cortisol levels are elevated as a result of reduced hepatic metabolism, hypoglycemia, and exposure to continuous levels of stress. According to Kimberling (1988), PT increases the size of the adrenal glands in response to increasing production of cortisol levels that may inhibit the use of glucose by tissues and cause clinical manifestations, especially associated with neurological signs. According to Reid (1960), this inhibitory effect on glucose utilization may be increased under conditions of severe insulin insufficiency. This fact was verified in the cases under study, in which there was a high negative correlation between cortisol and insulin $(r=-0.71)$.

The macroscopic alterations found in the livers of the animals with PT are in agreement with those found by Kabakci et al. (2003), who in animals with good body condition, when necropsied, observed the liver with pale yellow coloration, increased in size and easily friable, suggesting extensive fatty infiltration. According to Andrews (1997), it varies from pale pink to yellowish orange, is often greasy to the touch and in some cases will float in water. The literature does not make any provisos about the differentiation of the macroscopic findings of livers between sheep with type I and type II PT, although there was a difference in this study.

Macroscopically, there were no significant alterations in the kidneys (Andrews 1997, Radostits et al. 2007), with only paleness of the surface and cortex (Parry \& Taylor 1956) in some of the lean animals and slight yellowing in fatty animals.

In microscopy, massive lipid levels were observed in hepatocytes in spontaneous (Kabakci et al. 2003) and induced cases of PT (Cal et al. 2009). This alteration is related to the lipomobilization caused by the great energy demand due to gestation (Kabakci et al. 2003, Cal et al. 2009). This was also observed in the present study, especially in the sheep of Group 2.

Regarding the distribution of lesions, Cullen (2009) states that in mild cases the vacuolated hepatocytes are concentrated in the centrilobular region. This fact was not confirmed in the animals of Group 1, in which the lesions 
in the periportal zone predominated (71.43\%), unlike the centrilobular lesions (28.57\%). However, the findings of Group 2 corroborate Cullen (2009), where the majority of the vacuolations were distributed throughout the three zones, reflecting a considerably enlarged organ with an extremely greasy texture.

The histopathology findings of the kidneys, as well as those of the liver, are associated with metabolic disorders, being similar to those found by Parry \& Taylor (1956). These authors did not observe specific morphological alterations in the kidneys of the sheep with PT that died, except for unusual amounts of fat in the tubules, according to the findings of the disease in humans. These observations suggest that renal changes in sheep with PT could be purely functional and mainly reversible as in humans. It can be observed that there is a strong relation between body condition score and vacuolations in liver and kidney cells. Thus, the animals of Group 1 demonstrate scant vacuolization of hepatocytes, being little accompanied by vacuolization of cells of the renal epithelium.

It is interesting to mention the finding in one of the animals in Group 2, which presented unusual hepatocyte vacuolization and was necropsied two months after the diagnosis of gestation toxemia, with histological characteristics of the liver that returned to the initial pattern, as addressed by Cal et al. (2009) who observed this regenerative dynamic 60 days after PT induction, a fact corroborated by Parry \& Taylor (1956) who noticed reversibility of lesions in the affected sheep's kidneys, supposing that in this animal cellular regeneration also occurred.

\section{CONCLUSION}

Metabolic disorders in sheep associated with hepatic and renal lesions are more apparent in overweight animals and with a predominance of vacuolization. With higher impairment of hepatic and renal function, the clinical prognosis of animals with a high body score can be considered reserved.

Acknowledgements.- To the Foundation of Science and Technology Support of the State of Pernambuco (FACEPE) for the granting of the Master's degree.

Conflict of interest statement.- The authors have no competing interests.

\section{REFERENCES}

Afonso J.A.B. 2006. Toxemia da prenhez. Vet. Zootec. 26:7.

Andrews A. 1997. Pregnancy toxaemia in the ewe. In Practice 19(6):306-312. $<$ http://dx.doi.org/10.1136/inpract.19.6.306>

Andrews A.H., Holland-Howes V.E. \& Wilkinson J.I.D. 1996. Naturally occurring pregnancy toxaemia in the ewe and treatment with recombinant bovine somatotopin. Small. Rumin. Res. 23(2/3):191-197. <http://dx.doi. org/10.1016/S0921-4488(96)00912-1>

Araújo C.A.S.C. 2009. Estudo comparativo do perfil metabólico e hormonal de ovelhas com gestação única, gemelar e não gestantes alimentadas com dieta de alta densidade energética. Master's Thesis, Universidade de São Paulo, São Paulo. 212p. Available at <http://www.teses.usp.br/teses/ disponiveis/10/10136/tde-21092010-162531/pt-br.php> Accessed on Jun. 18, 2019.

Araújo D.F. \& Silva I.P. 2008. Valores de amilase, glicose, colesterol e triglicérides em soro de cabras de Mossoró, RN. Acta Vet. Bras. 2(3):97-100.

Armbruster D.A. 1987. Fructosamine: structure, analysis, and clinical usefulness. Clin. Chem. 33(12):2153-2163. <PMid:3319287>
Barakat S.E.M., Al-Bhanasawi N.M., Elazhari G.E. \& Bakhiet A.O. 2007. Clinical and serobiochemical studies on naturally ocurring pregnancy toxaemia in Shamia goats. J. Anim Vet. Adv. 6(6):768-772.

Barioni G., Fonteque J.H., Paes P.R.O., Takahira R.K., Kohayagawa A., Lopes R.S., Lopes S.T.A. \& Crocci A.J. 2001. Valores séricos de cálcio, fósforo, sódio, potássio e proteínas totais em caprinos fêmeas da raça parda alpina. Ciência Rural 31(3):435-438. http://dx.doi.org/10.1590/S010384782001000300011 .

Bernstein R.E. 1987. Nonenzymatically glycosilated proteins. Adv. Clin. Chem. 26:1-78. <http://dx.doi.org/10.1016/S0065-2423(08)60321-2> $<$ PMid:3307325>

Brockman R.P. 1979. Roles for insulin and glucagon in the development of ruminant ketosis, a review. Can. Vet. J. 20(5):121-126. <PMid:385136>

Brozos C., Mavrogianni V.S. \& Fthenakis G.C. 2011. Treatment and control of peri-parturient metabolic diseases: pregnancy toxemia, hypocalcemia, hypomagnesemia. Vet. Clin. N. Am., Food Anim. Pract. 27(1):105-113. <http://dx.doi.org/10.1016/j.cvfa.2010.10.004> <PMid:21215894>

Cal L., Borteiro C., Benech A., Rodas E., Abreu M.N., Cruz J.C. \& González Montaña J.R. 2009. Histological changes of the liver and metabolic correlates in ewes with pregnancy toxemia. Arq. Bras. Med. Vet. Zootec. 61(2):306-312. <http://dx.doi.org/10.1590/S0102-09352009000200004>

Cantley C.E.L., Ford C.M. \& Heath M.F. 1991. Serum fructosamine in ovine pregnancy toxaemia: a possible prognostic index. Vet. Rec. 128(22):525526. <http://dx.doi.org/10.1136/vr.128.22.525><PMid:1866884>

Carvalho C.C.D. 2013. Indicadores preditivos e controle para a toxemia da prenhez em ovelhas. Doctoral Dissertation in Veterinary Science, Universidade Federal Rural de Pernambuco, Recife.117p.

Cerón J.J., García Partida P., Sotillo J., Bayón A. \& Gutiérrez Panizo C. 1994. Serum protein and protein electrophoretic pattern variations in goats with ketosis during various stages of reproduction. Proceedings XVIII World Buiatrics Congress, Italia, p.1309-1313. (Resumo).

Chiquette J., Girard C.L. \& Matte J.J. 1993. Effect of diet and folic acid addition on digestibility and ruminal fermentation in growing steers. J. Anim. Sci. 71(10):2793-2798. <http://dx.doi.org/10.2527/1993.71102793x> <PMid:8226382>

Contreras P.A. \& Wittwer F. 2000. Uso dos perfis metabólicos no monitoramento nutricional dos ovinos, p.75-88. In: González F.H.D., Ospina H., Barcelos J.O. \& Ribeiro L.A.O. (Eds), Perfil Metabólico em Ruminantes: seu uso em nutrição e doenças nutricionais. Gráfica UFRGS, Porto Alegre. 108p.

Corrêa M.N., González F.H.D. \& Silva S.C. 2010. Transtornos Metabólicos dos Animais Domésticos. Universitária PREC-UFPEL, Pelotas, p.520.

Cullen J.M. 2009. Fígado, sistema biliar e pâncreas exócrino, p.393-462. In: McGavin M.D. \& Zachary J.F. (Eds), Bases da Patologia em Veterinária. 4th ed. Elservier, Rio de Janeiro, p.393-461.

Dirksen G., Gründer H.D., Stöber M. \& Rosenberger G. 1993. Exame Clínico dos Bovinos. 3rd ed. Guanabara Koogan, Rio de Janeiro. 419p.

Firat A. \& Özpinar A. 2002. Metabolic profile of pre-pregnancy, pregnancy and early lactation in multiple lambing Sakiz ewes. 1. Changes in plasma glucose, 3-hydroxybutyrate and cortisol levels. Ann. Nutr. Metabol. 46(2):57-61. <http://dx.doi.org/10.1159/000057641><PMid:12011573>

González F.H.D. \& Silva S.C. 2006. Introdução à Bioquímica Clínica Veterinária. Gráfica UFRGS, Porto Alegre. 357p.

González F.H.D., Hernández F., Madrid J., Martínez-Subiela S., Cerón J.J. \& Tecles F. 2012. Acid-base and electrolyte status during early induced pregnancy toxaemia in goats. Vet. J. 193(2):598-599. <http://dx.doi.org/10.1016/j. tvjl.2011.11.022><PMid:22192407>

Harmeyer J. \& Schlumbohm C. 2006. Pregnancy impairs ketone body disposal in late gestating ewes: implications for onset of pregnancy toxaemia. Vet. Sci. 81(2):254-264. <http://dx.doi.org/10.1016/j.rvsc.2005.10.010> $<$ PMid:16427105> 
Harmon D.L. 1993. Nutritional regulation of postruminal digestive enzymes in ruminants. J. Dairy Sci. 76(7):2102-2111. <http://dx.doi.org/10.3168/ jds.S0022-0302(93)77545-1> <PMid:8345133>

Hefnawy A.E., Youssef S. \& Shousha S. 2010. Some immunohormonal changes in experimentally pregnant toxemic goats. Vet. Med. Int. 4:768438. <http:// dx.doi.org/10.4061/2010/768438> <PMid:20613964>

Hefnawy A.E., Shousha S. \& Youssef S. 2011. Hematobiochemical profile of pregnant and experimentally pregnancy toxemic goats. J. Basic Appl. Chem. 1:65-69.

Henze P., Bickhardt K., Fuhrmann H. \& Sallmann H.P. 1998. Spontaneous pregnancy toaxemia (Ketosis) in sheep and the role of insulin. J. Am. Vet. Med. Assoc. 45:225-226.

Ismail Z.A., Al-Majali A.M., Amireh F. \& Al-Rawashdeh O.F. 2008. Metabolic profiles in goat does in late pregnancy with and without subclinical pregnancy toxemia. Vet. Clin. Pathol. 37(4):434-437. <http://dx.doi. org/10.1111/j.1939-165X.2008.00076.x> <PMid:19055580>

Jeffrey M. \& Higgins R.J. 1992. Brain lesions of naturally occurring pregnancy toxemia of sheep. Vet. Pathol. 29(4):301-307. <http://dx.doi. org/10.1177/030098589202900404><PMid:1514216>

Kabakci N., Yarim G., Yarim M., Duru Ö., Yagci B.B. \& Kisa Ü. 2003. Pathological, clinical and biochemical investigation of naturally occurring pregnancy toxemia of sheep. Acta Vet. 53(2/3):161-169.

Kaneko J.J., Harvey J.W. \& Bruss M.L. 2008. Clinical Biochemistry of Domestic Animals. 6th ed. Academic Press, San Diego. 916p.

Kimberling C.V. 1988. Jensen and Swift's: diseases of sheep. 3rd ed. Lea and Febiger, Philadelphia. 394p.

Lima M.S., Pascoal R.A. \& Stilwell G.T. 2012. Glycaemia as a sign of the viability of the foetuses in the last days of gestation in dairy goats with pregnancy toxaemia. Ir. Vet. J. 65:1. <http://dx.doi.org/10.1186/2046-0481-65-1> <PMid:22269111>

Little T.M. \& Hills F.J. 1978. Agricultural Experimentation: design and analysis. John Wiley, New York. 350p.

Moghaddam G. \& Hassanpour A. 2008. Comparison of blood serum glucose, beta hidroxybutiric acid, blood urea nitrogen and calcium concentrations in pregnant and lambed ewes. J. Anim. Vet. Adv. 7(3):308-311.

Murphy D., Reid S.W.J., Graham P.A. \& Love S. 1997. Fructosamine measurement in ponies: validation and response following experimental cyathostome infection. Res. Vet. Sci. 63(2):113-118. <http://dx.doi.org/10.1016/S00345288(97)90002-3> <PMid:9429242>

Ortolani E.L. 2004. Toxemia da prenhez em pequenos ruminantes: como reconhecê-la e evitá-la. Available at <https://www.monografias.com/pt/ trabalhos901/toxemia-prenhez-ruminantes/toxemia-prenhez-ruminantes. shtml> Accessed on Dec. 11, 2004.

Parry H.B. \& Taylor W.H. 1956. Renal function in sheep during normal and toxaemic pregnancies. J. Physiol. 131(2):383-392. <http://dx.doi. org/10.1113/jphysiol.1956.sp005469> <PMid:13320341>

Payne J.M. 1983. Enfermedades Metabolicas de los Animales Zootecnicos. Editorial Acribia, Zaragoza, España. 218p.

Pereira R.A., Schmitt E., Schneider A., Del Pino F.A.B. \& Corrêa M.N. 2010. Adaptação metabólica em ovelhas gestantes e não gestantes submetidas ao teste de tolerância à glicose. Anais do XIX Congresso de Iniciação Científica, Núcleo de Pesquisa, Ensino e Extensão em Pecuária, Universidade Federal de Pelotas, Pelotas, RS. (Resumo)

Petterson J.A., Dunshea F.R., Ehrhardt R.A. \& Bell A.W. 1993. Pregnancy and undernutrition alter glucose metabolic responses to insulin in sheep. J. Nutr. 123(7):1286-1295. <http://dx.doi.org/10.1093/jn/123.7.1286> <PMid:8320567>

Radostits O.M., Gay C.C., Hinchcliff K.W. \& Constable P.D. 2007. Veterinary Medicine: a textbook of the diseases of cattle, horses, sheep, pigs and goats. 10 th ed. W.B. Saunders, St Louis. 2156p.
Reece W.0. 2006. Função renal nos mamíferos, p.67-96. In: Ibid. (Ed.), Dukes, Fisiologia dos Animais Domésticos. Guanabara Koogan, Rio de Janeiro.

Reid R.L. 1960. Studies on the carbohydrate metabolism of sheep. XI. The role of the adrenals in ovine pregnancy toxaemia. Aust. J. Agric. Res. 11(3):364-382.<https://doi.org/10.1071/AR9600364>

Regnault T.R., Oddy H.V., Nancarrow C., Sriskandarajah N. \& Scaramuzzi R.J. 2004. Glucose: stimulated insulin response in pregnant sheep following acute suppression of plasma non-sterifield fatty acid concentrations. Reprod. Biol. Endocrinol. 2:64. <PMid:15352999>

Santos F.C.O., Mendonça C.L., Silva Filho A.P., Carvalho C.C.D., Soares P.C. \& Afonso J.A.B. 2011. Indicadores bioquímicos e hormonais de casos naturais de toxemia da prenhez em ovelhas. Pesq. Vet. Bras.31(11):974-980.<http:// dx.doi.org/10.1590/S0100-736X2011001100006>

SAS 2009. Inc SAS User's Guide: statics version. Statistical Analyses Sistem Institute, Cary, NC.

Schlumbohm C. \& Harmeyer J. 2003. Hipocalcemia reduces endogenous glucose production in hiperketonemic sheep. J. Dairy Sci. 86(6):1953-1962.<http:// dx.doi.org/10.3168/jds.S0022-0302(03)73783-7><PMid:12836930>

Schlumbohm C., Sporleder H.P., Gürtler H. \& Harmeyer J. 1997. The influence of insulin on metabolism on glucose, free fatty acids and glycerol in normo and hypocalcemic ewes during different reproductive states. Dtsch. Tierärztl. Wschr. 104:359-365.

Schulla V., Renström E., Feil R., Feil S., Franklin I., Gjinovci A., Jing X.-J., Laux D., Lundquist I., Magnuson M.A., Obermüller S., Olofsson C.S., Salehi A., Wendt A., Klugbauer N., Wollheim C.B., Rorsman P. \& Hofmann F. 2003. Impaired insulin secretion and glucose tolerance in $\beta$ cell-selective Cav1.2 Ca2+ channel null mice. EMBO J. 22(15):3844-3854. <http://dx.doi. org/10.1093/emboj/cdg389><PMid:12881419>

Scott P.R., Sargison N.D., Penny C.D., Pirie R.S. \& Kelly J.M. 1995. Cerebrospinal fluid and plasma glucose concentrations of ovine pregnancy toxaemia cases, inappetant ewes and normal ewes during late gestation. Brit. Vet. J. 151(1):39-44. <http://dx.doi.org/10.1016/S0007-1935(05)80063-6> $<$ PMid:7735869>

Sigurdsson H. 1991. Metabolic disorders in ewes during late pregnancy. Icel. Agric. Sci. 5:25-31.

Strobel H.J. 1992. Vitamin B12-dependent propionate production by the ruminal bacterium Prevotella ruminicola 23. Appl. Environ. Microbiol. 58(7):2331-2333. <PMid:1637169>

Van Hellen R.W., Wilson T.A., Mitchell Junior G.E., Schelling G.T. \& Tucker R.E. 1978. Bovine amylase, insulin and glucose response to high and low concentrate diets. J. Anim. Sci. 47(1):445.

Van Saun R.J. 2000. Pregnancy toxemia in a flock of sheep. J. Am. Vet. Med. Assoc. 217(10):1536-1539. <http://dx.doi.org/10.2460/javma.2000.217.1536> <PMid:11128547>

Wastney M.E., Wolff J.E. \& Bickerstaffe R. 1983. Glucose turnover and hepatocyte glucose production of starved and toxaemic pregnant sheep. Aust. J. Biol. Sci. 36(3):271-284. <http://dx.doi.org/10.1071/BI9830271> <PMid:6651639>

Wierda A., Verhoeff S., Van Dijk S., Dorresteijnd J. \& Wensing T. 1985. Effects of trenbolone acetate and propyleneglycol on pregnancy toxaemia in ewes. Vet. Rec. 116(11):284-287. <http://dx.doi.org/10.1136/vr.116.11.284> <PMid:3992831>

Yarim G.F. \& Ciftci G. 2009. Serum protein pattern in ewe with pregnancy toxemia. Vet. Res. Commun. 33(5):431-438. <http://dx.doi.org/10.1007/ s11259-008-9189-9><PMid:19031107>

Zinn R.A., Owens F.N., Stuart R.L., Dunbar J.R. \& Norman B.B. 1987. B-vitamin supplementation of diets for feedlot calves. J. Anim. Sci. 65(1):267-277. <http://dx.doi.org/10.2527/jas1987.651267x> <PMid:3610874> 